Note

\title{
TERMITE ACTIVITY IN RELATION TO NATURAL GRASSLAND SOIL ATTRIBUTES
}

\author{
Glaciela Kaschuk ${ }^{1,2}$; Julio Cesar Pires Santos ${ }^{3 *}$; Jaime Antonio Almeida ${ }^{3}$; Deise Cristina \\ Sinhorati ${ }^{3}$; João Francisco Berton-Junior ${ }^{3}$ \\ ${ }^{1}$ Embrapa Soja - Lab. de Biotecnologia de Solos, C.P.231 - 86001-970 - Londrina, PR-Brasil. \\ ${ }^{2}$ WUR-Plant Production Systems Group, PO Box 430 - 6700 AK - Wageningen - The Netherlands. \\ ${ }^{3}$ UDESC/CAV-Depto. de Solos, C.P.281 - 88520-000 - Lages, SC - Brasil. \\ *Corresponding author <a2jcps@cav.udesc.br>
}

\begin{abstract}
Soil-feeding termites transport soil for mound building, and this process can affect soil characteristics. To verify the influence of soil termite activity on soil characteristics, samples were collected from top, bottom and center of termite mounds, and of the adjacent area, to assess chemical and physical properties and mineralogical composition. Four replicates of termite mounds and respective adjacent areas were randomly sampled in Lages, Capão Alto, Painel, São José do Cerrito and Coxilha Rica (State of Santa Catarina, southern Brazil). Results of chemical analyses showed a greater content of K, P, $\mathrm{Ca}, \mathrm{Mg}$ and organic $\mathrm{C}$ in the inner part of termite mounds, accompanied by lower $\mathrm{pH}$ in relation to soil of the adjacent area. There were no differences regarding clay mineral composition between termite mounds and adjacent soil, however the proportion of sand and clay differed between them. It is concluded that termites modify soil characteristics due to great volume of soil transported per ascensum for mound construction (varying from $20.9 \mathrm{~m}^{3} \mathrm{ha}^{-1}$ to $136.6 \mathrm{~m}^{3} \mathrm{ha}^{-1}$, in this study) which promotes a strong pedo-bioperturbation and affects nutrient cycling and soil physical properties.
\end{abstract}

Key words: chemical and physical soil properties, clay minerals, soil biology, termite mounds

\section{ATIVIDADE DE TÉRMITASEMRELAÇÃO A ATRIBUTOS DE SOLOS SOB CAMPO NATIVO}

\begin{abstract}
RESUMO: Os térmitas (cupins) do solo carregam partículas de solo para construção de seus ninhos e desta forma, podem afetar algumas características pedológicas. Este estudo teve como objetivo verificar a influência da atividade de térmitas nas características do solo através de análises das propriedades químicas e físicas e da composição mineralógica de amostras coletadas na base, topo e centro dos ninhos e área de solo adjacente. Quatro cupinzeiros e suas respectivas áreas adjacentes foram aleatoriamente amostrados em Lages, Capão Alto, Painel, São José do Cerrito e Coxilha Rica (Santa Catarina). Os resutados das análises químicas mostraram que o conteúdo de $\mathrm{K}, \mathrm{P}, \mathrm{Ca}, \mathrm{Mg}$ e C orgânico no centro dos ninhos foi maior e o pH menor em relação à área de solo adjacente. Não houve diferenças na composição dos argilominerais entre os ninhos e as áreas adjacentes, no entanto, a composição granulométrica dos solos diferiu entre os dois locais. Térmitas podem modificar outras características do solo, tais como as propriedades físicas e químicas, devido ao elevado volume de solo transportado per ascensum para construção dos cupinzeiros (entre 20,9 $\mathrm{m}^{3} \mathrm{ha}^{-1}$ e $136,6 \mathrm{~m}^{3} \mathrm{ha}^{-1}$ neste estudo) que promove a bioturbação e afeta a ciclagem de nutrientes.

Palavras-chave: propriedades químicas e físicas do solo, argilominerais, biologia do solo, cupinzeiros
\end{abstract}

\section{INTRODUCTION}

Termites are social insects of the order Isoptera with about 3,000 known species, of which $75 \%$ are classified as soil-feeding termites. The diet of soil-feeding termites consists of no-cellular organic material mixed with clay minerals. Their gut is formed by five compartments that present rising gradients of $\mathrm{pH}$, up to 12.5 , and different status of oxygen and hy- drogen (Brune et al., 1995; Brune \& Kühl, 1996; Donovan et al., 2001; Eggleton \& Tayasu, 2001). These characteristics are certainly important and may effectively contribute to mound soil chemical and physical characteristics.

Termites are recognized as "ecosystem engineers" (Dangerfield et al., 1998) because they promote soil transformations by disturbance processes. They collect particles from different soil depths and deposit 
them in mounds, so that contents of organic C, clay and nutrients, $\mathrm{pH}$ and microbial population increase higher in termite mounds in relation to adjacent soils (Lal, 1988; Black \& Okwakol, 1997; Holt, 1998; Ohkuma, 2003). The accumulated material is later redistributed by erosion causing changes in soil microstructure and fertility (Lee \& Wood, 1971; Black \& Okwakol, 1997; Dangerfield et al., 1998; Jungerius et al., 1999; Shaefer, 2001). Termites also build a vast network of galleries that increase soil porosity and water infiltration (Mando \& Stroosnijder, 1999; Leónard $\&$ Rajot, 2001) and these galleries may be filled up with topsoil after rainfalls, contributing to the process of formation of latosols (Shaefer, 2001).

Clay content in termite mounds is usually $20 \%$ higher than in nearby soils, but it is not known whether termites select particles or soil undergoes a physical fractioning through the gut, or 2:1 clay minerals are modified to more expansible forms (Lee \& Wood, 1971; Donovan et al., 2001; Jouquet et al., 2002a; $2002 \mathrm{~b})$. It is possible that clay minerals are altered as soil particles are carried in their mouths or in their gut.

This study is a contribution to assess termite activity and understand its effects on soil clay mineralogy, chemical and physical attributes of different soils under natural grasslands in southern Brazil.

\section{MATERIAL AND METHODS}

Samples were taken at five locations in the Santa Catarina State, southern Brazil in September 2001. Location, altitude and major soil group (FAO, 1988) of the sites are: (i) Lages: $27^{\circ} 48^{\prime} \mathrm{S}, 50^{\circ} 19^{\prime} \mathrm{W}$; 937 m, Cambisol; (ii) Capão Alto: 275' $\mathrm{S}, 50^{\circ} 30^{\prime} \mathrm{W}$; 1022 m, Nitisol; (iii) Painel: $27^{\circ} 55^{\prime} \mathrm{S}, 50^{\circ} 06^{\prime} \mathrm{W} ; 1140$ m, Nitisol; (iv) São José do Cerrito: $27^{\circ} 40^{\prime} \mathrm{S}, 50^{\circ} 34^{\prime} \mathrm{W}$; 879 m, Nitisol; (v) Coxilha Rica (municipality of Lages): $1200 \mathrm{~m}$, Cambisol. One of the areas (Lages, (i)) was weed-infested by Eragrostis spp. The average rainfall in the region is $1,400 \mathrm{~mm} \mathrm{yr}^{-1}$. According to Köppen's classification the climate is type $\mathrm{Cfb}$. The annual average temperature in the region varies between $10^{\circ} \mathrm{C}$ and $16^{\circ} \mathrm{C}$ (Santa Catarina, 1986). The vegetation is characterized by natural grassland and the areas have been used for grazing for at least three decades. In each location, four soil termite mounds were randomly chosen and samples were collected with an auger from the center, top and bottom of the nest. In many cases, mound walls had to be broken with hammer due to the hardness of the mound. Two additional samples were collected with an auger, $1.5 \mathrm{~m}$ distant from opposite sides of the mound. The soil samples were dried at $60^{\circ} \mathrm{C}$ for 48 hours, ground and sieved $(2 \mathrm{~mm})$. Termites were hand-collected from samples and some individuals were kept in $80 \%$ alcohol. The termite species from Capão Alto were Grigiotermes bequaerti and Termes saltans; from Painel were Cornitermes cumulans and Cortaritermes fulviceps, and from Lages were Neocapritermes opacus, Cortaritermes fuviceps and Cornitermes cumulans. The species from Coxilha Rica and São José do Cerrito were not identified. The presence of different species does not affect conclusions because all species feed on organic matter available in the soil and use soil particles for mound building.

Calcium, $\mathrm{Mg}, \mathrm{P}, \mathrm{K}$, organic $\mathrm{C}, \mathrm{pH}$ in water and SMP analyses were made according to the methods described by Tedesco et al. (1985). Determination of particle size distribution was achieved as described in EMBRAPA (1979). Clay fraction samples were analyzed by X-Ray Diffraction for identification and differentiation of clay minerals in the samples according to Whittig \& Allardice (1986).

As parameter for termite activity, the volume of soil transported $\left(\mathrm{m}^{3} \mathrm{ha}^{-1}\right)$ was estimated with the equation $V=1 / 3 \cdot \pi \cdot R^{2} \cdot h$, where $R(\mathrm{~m})$ is radius of mound and $h(\mathrm{~m})$ is height of mound. The number of mounds per hectare was estimated counting the termite mounds in activity in a 0.5 ha area.

Analysis of variance was made using the PROG GLM, SAS 6.12 (SAS, 1999). The comparisons at $95 \%$ significance were also made with the Duncan test. The data on the volume of transported soil by termites was submitted to a descriptive analysis using the box plot option.

\section{RESULTS AND DISCUSSION}

Most of the areas of natural grassland in southern Brazil were developed on acid soils, with high levels of exchangeable $\mathrm{Al}$ and that have never been managed to improve soil quality and thus, soil productivity has to be maintained only through biological interference. The grazing habits of some termites could contribute for nutrient cycling, at the same time other termite groups (soil-feeding termites) could affect soil physical properties. In this study, contents of $\mathrm{P}, \mathrm{K}, \mathrm{Ca}, \mathrm{Mg}$ and organic $\mathrm{C}$ were higher in the centre of mounds than in the adjacent soil (Table 1), but top and bottom of termite mound presented no difference in relation to adjacent soil. For example, organic $\mathrm{C}$ was more than four-times-fold in the centre of nest than in the top, bottom and adjacent soil, though the nutrient levels varied according to the soil of each area. These results agree with findings elsewhere (Lee \& Wood, 1971; Watson, 1975; Sheikh \& Kayani, 1982; Black \& Okwakol, 1997; López-Hernández, 2001). Differences in $\mathrm{pH}$ (SMP), but not in water, were found in top of 
Table 1 - Chemical analyses of soil from different parts in termite mounds and adjacent soil in five different locations in Santa Catarina, Brazil*.

\begin{tabular}{|c|c|c|c|c|c|c|c|}
\hline Sample & $\mathrm{K}\left(\mathrm{mg} \mathrm{kg}^{-1}\right)$ & $\mathrm{P}\left(\mathrm{mg} \mathrm{kg}^{-1}\right)$ & $\mathrm{Ca}\left(\mathrm{cmol}_{\mathrm{c}} \mathrm{kg}^{-1}\right)$ & $\operatorname{Mg}\left(\mathrm{cmol}_{\mathrm{c}} \mathrm{kg}^{-1}\right)$ & $\mathrm{C}$ org $\left(\mathrm{g} \mathrm{kg}^{-1}\right)$ & $\mathrm{pH}$ water & $\mathrm{pH}$ SMP \\
\hline \multicolumn{8}{|l|}{ Capão Alto } \\
\hline Centre of mound & $31.20 \mathrm{a}$ & $12.23 \mathrm{NS}$ & $16.30 \mathrm{a}$ & $8.31 \mathrm{a}$ & $151.7 \mathrm{NS}$ & $4.76 \mathrm{NS}$ & $4.77 \mathrm{~b}$ \\
\hline Top of mound & $19.75 \mathrm{~b}$ & 2.27 & $5.55 \mathrm{~b}$ & $2.48 \mathrm{~b}$ & 44.6 & 4.93 & $5.17 \mathrm{a}$ \\
\hline Bottom of mound & $4.15 \mathrm{c}$ & 2.65 & $0.67 \mathrm{~b}$ & $0.43 \mathrm{~b}$ & 17.3 & 4.57 & $4.55 \mathrm{~b}$ \\
\hline Adjacent soil 1 & $10.22 \mathrm{c}$ & 0.77 & $2.25 \mathrm{~b}$ & $1.27 \mathrm{~b}$ & 34.4 & 4.73 & $4.60 \mathrm{~b}$ \\
\hline Adjacent soil 2 & $11.42 \mathrm{bc}$ & 1.47 & $1.83 \mathrm{~b}$ & $1.20 \mathrm{~b}$ & 38.9 & 4.64 & $4.50 \mathrm{~b}$ \\
\hline \multicolumn{8}{|l|}{ Coxilha Rica } \\
\hline Centre of mound & $30.50 \mathrm{a}$ & $78.04 \mathrm{a}$ & $3.82 \mathrm{NS}$ & $0.59 \mathrm{NS}$ & $154.3 \mathrm{a}$ & $4.23 \mathrm{NS}$ & $4.21 \mathrm{NS}$ \\
\hline Top of mound & $21.65 \mathrm{~b}$ & $50.87 \mathrm{ab}$ & 2.02 & 0.3 & $42.5 \mathrm{~b}$ & 4.62 & 4.44 \\
\hline Bottom of mound & $4.27 \mathrm{~d}$ & $3.37 \mathrm{~b}$ & 0.5 & 0.04 & $18.5 \mathrm{~b}$ & 4.42 & 4.16 \\
\hline Adjacent soil 1 & $12.97 \mathrm{c}$ & $7.11 \mathrm{~b}$ & 1.12 & 0.17 & $39.3 \mathrm{~b}$ & 4.28 & 4.1 \\
\hline Adjacent soil 2 & $11.29 \mathrm{~cd}$ & $4.28 \mathrm{~b}$ & 1.05 & 0.16 & $40.9 \mathrm{~b}$ & 4.31 & 4.09 \\
\hline \multicolumn{8}{|l|}{ São José do Cerrito } \\
\hline Centre of mound & $48.10 \mathrm{NS}$ & $75.90 \mathrm{a}$ & $9.97 \mathrm{a}$ & $1.43 \mathrm{NS}$ & $145.4 \mathrm{a}$ & $4.77 \mathrm{~b}$ & $4.87 \mathrm{c}$ \\
\hline Top of mound & 31.3 & $15.63 \mathrm{~b}$ & $5.20 \mathrm{~b}$ & 0.56 & $42.8 \mathrm{~b}$ & $5.14 \mathrm{ab}$ & $5.28 \mathrm{ab}$ \\
\hline Bottom of mound & 30.78 & $15.15 \mathrm{~b}$ & $2.77 \mathrm{~b}$ & 0.32 & $21.8 \mathrm{~b}$ & $4.82 \mathrm{~b}$ & $5.06 \mathrm{bc}$ \\
\hline Adjacent soil 1 & 31.2 & $4.82 \mathrm{~b}$ & $2.95 \mathrm{~b}$ & 0.37 & $26.8 \mathrm{~b}$ & $5.14 \mathrm{ab}$ & $5.07 \mathrm{bc}$ \\
\hline Adjacent soil 2 & 42.58 & $7.53 \mathrm{~b}$ & $3.67 \mathrm{~b}$ & 0.44 & $27.1 \mathrm{~b}$ & $5.38 \mathrm{a}$ & $5.38 \mathrm{a}$ \\
\hline \multicolumn{8}{|l|}{ Lages } \\
\hline Centre of mound & $37.52 \mathrm{a}$ & $30.82 \mathrm{a}$ & $14.32 \mathrm{a}$ & $8.34 \mathrm{a}$ & $122.7 \mathrm{a}$ & $4.57 \mathrm{NS}$ & $5.13 \mathrm{NS}$ \\
\hline Top of mound & $13.55 \mathrm{~b}$ & $2.20 \mathrm{~b}$ & $3.90 \mathrm{~b}$ & $1.96 \mathrm{~b}$ & $32.5 \mathrm{~b}$ & 4.78 & 4.77 \\
\hline Bottom of mound & $8.45 \mathrm{~b}$ & $0.44 \mathrm{~b}$ & $1.80 \mathrm{~b}$ & $0.79 \mathrm{~b}$ & $19.5 \mathrm{~b}$ & 4.41 & 4.28 \\
\hline Adjacent soil 1 & $12.17 \mathrm{~b}$ & $1.65 \mathrm{~b}$ & $2.80 \mathrm{~b}$ & $1.55 \mathrm{~b}$ & $28.6 \mathrm{~b}$ & 4.62 & 4.42 \\
\hline Adjacent soil 2 & $10.57 \mathrm{~b}$ & $2.30 \mathrm{~b}$ & $3.17 \mathrm{~b}$ & $1.93 \mathrm{~b}$ & $34.7 \mathrm{~b}$ & 4.79 & 4.54 \\
\hline \multicolumn{8}{|l|}{ Painel } \\
\hline Centre of mound & $18.15 \mathrm{NS}$ & $29.66 \mathrm{a}$ & $10.20 \mathrm{a}$ & $1.15 \mathrm{NS}$ & $143.5 \mathrm{NS}$ & $4.75 \mathrm{~b}$ & $4.55 \mathrm{~b}$ \\
\hline Top of mound & 22.07 & $31.37 \mathrm{a}$ & $5.10 \mathrm{~b}$ & 0.62 & 85.3 & $5.46 \mathrm{a}$ & $5.18 \mathrm{a}$ \\
\hline Bottom of mound & 8.47 & $7.47 \mathrm{~b}$ & $3.40 \mathrm{~b}$ & 0.36 & 35.5 & $4.81 \mathrm{~b}$ & $4.68 \mathrm{~b}$ \\
\hline Adjacent soil 1 & 10.35 & $5.33 \mathrm{~b}$ & $1.80 \mathrm{~b}$ & 0.23 & 29.1 & $4.88 \mathrm{~b}$ & $4.70 \mathrm{~b}$ \\
\hline Adjacent soil 2 & 10.02 & $4.05 \mathrm{~b}$ & $1.85 \mathrm{~b}$ & 0.25 & 29 & $4.87 \mathrm{~b}$ & $4.66 \mathrm{~b}$ \\
\hline
\end{tabular}

*Means followed by different letters within columns differ significantly by Duncan test at $5 \%$ of significance. NS: non significant $(\operatorname{Pr}>\mathrm{F})$.

nest of mounds in some areas such as in Capão Alto and Painel. This fact is relevant because soil fertility of the surrounding soil may be increased when rainfalls erode the mounds and spread nutrients on soil surface (Lee \& Wood, 1971; Dangerfield et al., 1998) especially when nests are abandoned. To date, a shifting of plant composition around the termite mounds has been reported in Africa due to the soil fertilization by termite activity (Dangerfield et al., 1998).

Clay content is higher in termite mounds than in the adjacent soil, probably, due to their preference for finer soil particles as a cementing material for constructing their nests (Lee \& Wood, 1971; Donovan et al., 2001). However, in this study, no differences were found in clay content among adjacent soil, bottom and top of mound (Table 2), but a lower content was observed in the centre of mound, where sand content was higher (areas of Lages, Capão Alto and Painel). Probably, higher sand content provides better conditions for draining and controlling humidity and aeration in the centre of nest in the clayey soils.

Pioneer studies demonstrated some modifications in soil texture or clay minerals by the action of termites (Donovan et al., 2001; Jouquet et al., 2002b). Soil particles probably undergo modifications through the gut because of the extremely alkaline $\mathrm{pH}$, reaching values up to 12 (Brune \& Kühl, 1996; Brauman, 2000; Ohkuma, 2003) and for this reason, P may be 
Table 2 - Soil textural analyses from different parts of termite mounds and adjacent soil of five different locations in Santa Catarina, Brazil.*

\begin{tabular}{|c|c|c|c|}
\hline Sample & Sand $\left(\mathrm{g} \mathrm{kg}^{-1}\right)$ & Clay $\left(\mathrm{g} \mathrm{kg}^{-1}\right)$ & Silt $\left(\mathrm{g} \mathrm{kg}^{-1}\right)$ \\
\hline \multicolumn{4}{|l|}{ Capão Alto } \\
\hline Centre of mound & $376 \mathrm{a}$ & $312 \mathrm{~b}$ & $312 \mathrm{NS}$ \\
\hline Top of mound & $205 \mathrm{~b}$ & $612 \mathrm{a}$ & 183 \\
\hline Bottom of mound & $147 \mathrm{~b}$ & $675 \mathrm{a}$ & 178 \\
\hline Adjacent soil 1 & $121 \mathrm{~b}$ & 592 a & 287 \\
\hline Adjacent soil 2 & $174 \mathrm{~b}$ & 666 a & 160 \\
\hline \multicolumn{4}{|l|}{ Coxilha Rica } \\
\hline Centre of mound & $220 \mathrm{NS}$ & $583 \mathrm{NS}$ & $197 \mathrm{NS}$ \\
\hline Top of mound & 121 & 654 & 225 \\
\hline Bottom of mound & 100 & 800 & 100 \\
\hline Adjacent soil 1 & 173 & 637 & 190 \\
\hline Adjacent soil 2 & 180 & 612 & 208 \\
\hline \multicolumn{4}{|l|}{ São José do Cerrito } \\
\hline Centre of mound & $29.2 \mathrm{NS}$ & $408 \mathrm{NS}$ & $300 \mathrm{a}$ \\
\hline Top of mound & 209 & 642 & $149 \mathrm{bc}$ \\
\hline Bottom of mound & 116 & 754 & $130 \mathrm{c}$ \\
\hline Adjacent soil 1 & 123 & 691 & $186 \mathrm{bc}$ \\
\hline Adjacent soil 2 & 144 & 646 & $210 \mathrm{~b}$ \\
\hline \multicolumn{4}{|l|}{ Lages } \\
\hline Centre of mound & 459 a & $304 \mathrm{~b}$ & $237 \mathrm{~b}$ \\
\hline Top of mound & $164 \mathrm{~b}$ & $491 \mathrm{a}$ & $345 \mathrm{a}$ \\
\hline Bottom of mound & $205 \mathrm{~b}$ & 479 a & $316 \mathrm{a}$ \\
\hline Adjacent soil 1 & $204 \mathrm{~b}$ & $454 \mathrm{a}$ & 342 a \\
\hline Adjacent soil 2 & $196 \mathrm{~b}$ & $483 \mathrm{a}$ & $321 \mathrm{a}$ \\
\hline \multicolumn{4}{|l|}{ Painel } \\
\hline Centre of mound & $501 \mathrm{a}$ & $337 \mathrm{NS}$ & $162 \mathrm{NS}$ \\
\hline Top of mound & $370 \mathrm{ab}$ & 408 & 222 \\
\hline Bottom of mound & $142 \mathrm{~b}$ & 617 & 241 \\
\hline Adjacent soil 1 & $140 \mathrm{~b}$ & 633 & 227 \\
\hline Adjacent soil 2 & $164 \mathrm{~b}$ & 596 & 240 \\
\hline
\end{tabular}

*Means followed by different letters within columns differ significantly by Duncan test at $5 \%$ of significance. NS: non significant $\operatorname{Pr}>\mathrm{F})$.

released from the $\mathrm{Al}$ and $\mathrm{Fe}-\mathrm{P}$ forms in soils (Shaefer, 2001), humic composts in the soil matrix may be dissociated by an alkaline incubation or microorganisms may be digested (Brune \& Kühl, 1996; Ji et al., 2000). However, although the role of an alkaline environment in the termite gut is still unclear, there is strong evidence that the high $\mathrm{pH}$ is related to potassium transport and a detailed mechanism commanded by $\mathrm{K}^{+}$ATPase, resulting $\mathrm{K}_{2} \mathrm{CO}_{3}$ accumulation (Brune \& Kühl, 1996).

Micas form vermiculite (or smectite) by weathering, releasing $\mathrm{K}^{+}$and replacing other exchangeable cations, mainly $\mathrm{Ca}^{+2}$ and $\mathrm{Mg}^{+2}$ (Schulze, 2002). Following this reasoning, it could be speculated that
2:1 clay minerals, rich in $\mathrm{K}^{+}$, would be modified during the construction of termite mounds because of $\mathrm{K}^{+}$ extraction from clay minerals by a biological metabolism of soil-feeding termites, by which free charges would be neutralized with cations from organic matter, such as $\mathrm{Al}^{+3}$, very abundant in most soils of south Brazil.

Expressive differences in quality and quantity of clay minerals among samples from adjacent soil, top, centre and bottom of termite mounds were, however, not observed. Illustrative examples for the mineralogy of soil derived from sedimentary and basaltic rocks are given in figures 1 and 2, respectively. In Lages, where Cambisols are derived from siltites, clay 


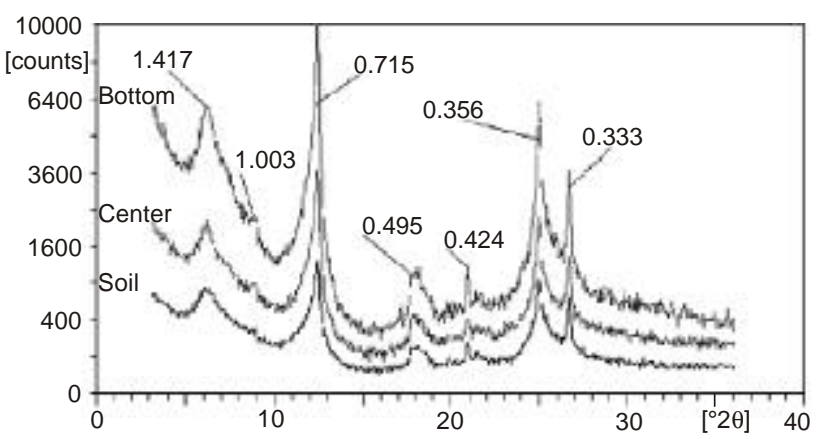

Figure 1 - Mineralogical composition of soil samples collected in bottom, center and adjacent soil of termite mounds in Lages, SC. Values of displacement, in $\eta \mathrm{m}$, representing expansible 2:1 clay minerals (1.417), micas (1.003 and $0.495)$, Kaolinite (0.715 and 0.356), and quartz (0.424 and 0.333 ).

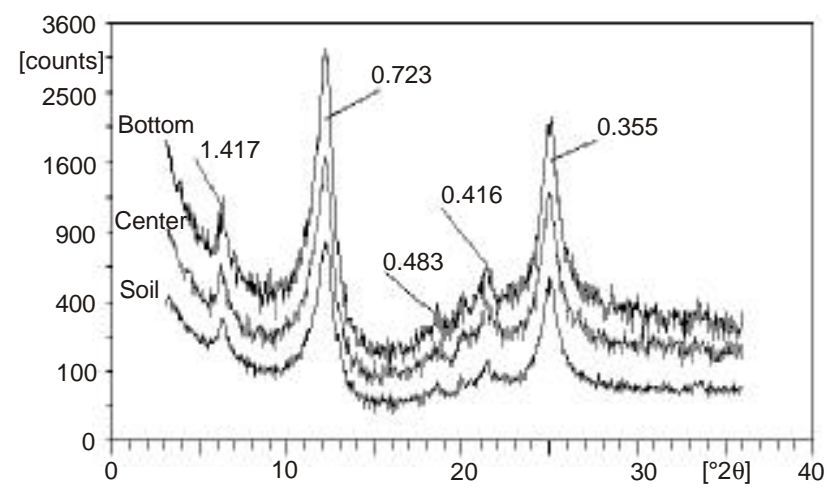

Figure 2 - Mineralogical composition of soils samples collected in bottom, center and adjacent soil of termite mounds in Painel, SC. Values of displacement, in $\eta \mathrm{m}$, representing expansible representing 2:1 clay minerals (1.417), Kaolinite (0.723), gibbsite (0.483) and goethite (0.416).

minerals are dominated by kaolinite (peaks of 0.715 and $0.356 \mathrm{\eta m}$ ), seconded by Al-hydroxy-interlayered vermiculite (HIV) (peaks of $1.417 \eta \mathrm{m}$ ), micas illite (peaks of 1.003 and $0.495 \eta \mathrm{m}$ ) and quartz (peaks of 0.424 and $0.333 \eta \mathrm{m}$ ) (Figure 1). There were no significant variations in clay mineral compositions in samples from adjacent soil, centre and bottom of termite mound. The asymmetry of kaolinite peaks in direction to lower angles $2 \theta$ indicates that kaolinites have interstratifications of 2:1 layers in small proportions. In Painel, where soils are derived from basaltic rock, the mineralogical composition was also similar among soil samples of centre and bottom of termite mounds and adjacent soil (Figure 2). Kaolinite was also the dominant clay mineral (peaks of 0.723 and $0.355 \eta \mathrm{m}$ ), but differently from the soils decomposed from siltites of Lages, the presence of 2:1 clay minerals (HIV peaks of $1.417 \eta \mathrm{m}$ ) was less with no presence of il- lite. Peaks around of $0.48 \mathrm{\eta m}$ indicated a small amount of $\mathrm{Al}$ oxide (gibbsite) and peaks of $0.416 \eta \mathrm{m}$ a presence of Fe oxide (goethite).

The similarity in mineralogical components revealed that the activity of the termites in southern Brazilian soils apparently does not promote qualitative alterations in the clay mineralogy such as those evidenced elsewhere (Jouquet et al., 2002b). We assume that our results were due to the high stability of the clay minerals present in these soils, predominantly composed by kaolinite and HIV.

Even though termites did not affect soil mineralogical composition by altering phyllosilicates, it cannot be disregarded that termites can continuously modify other morpho-physical and pedogenetic characteristics, improving soil quality especially because of bioturbation and gallery constructions. In this study, termite activity was associated with the volume of soil transported by termites in five different locations. The total volume of soil transported varied in average from $20.9 \mathrm{~m}^{3} \mathrm{ha}^{-1}$ in Coxilha Rica to $136.6 \mathrm{~m}^{3} \mathrm{ha}^{-1}$ in Painel and the volume of soil transported to above the level of surface oscillated from $8.11 \mathrm{~m}^{3} \mathrm{ha}^{-1}$ in Coxilha Rica to $63.3 \mathrm{~m}^{3} \mathrm{ha}^{-1}$ in Painel (Figure 3). The intensity of this activity was associated to the amount of termite mounds, which was estimated in 300 mounds per ha in Lages, 270 in Capão Alto, 518 in Painel, 360 in Coxilha Rica and 315 in São José do Cerrito (Figure 3 ). On the basis of these numbers, it is suggested that effects on soil properties are very important as long as the population and activity of termites are not affected by intensive soil use (Miklós, 1993, 1995; Black \& Okwakol, 1997; Jones et al., 2003).

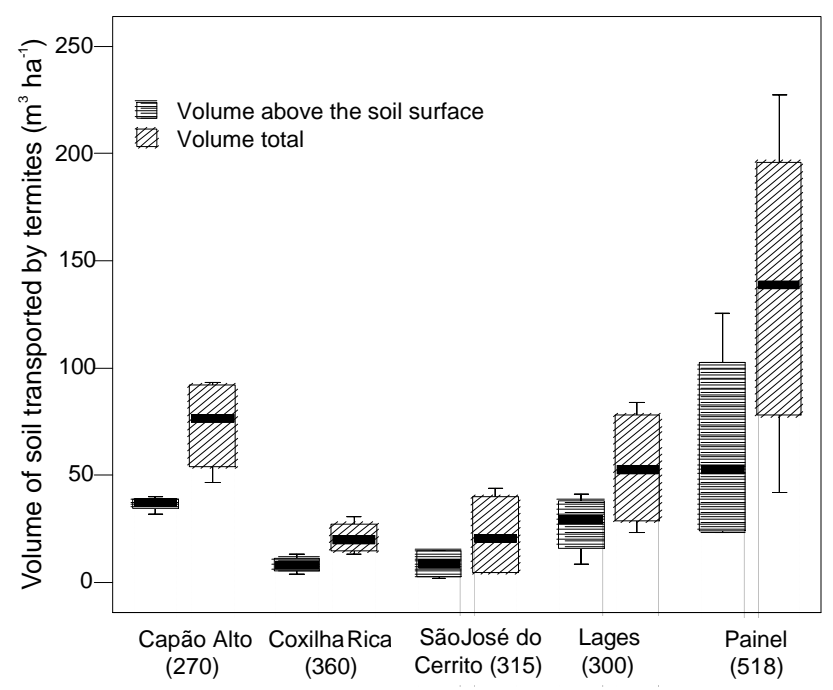

Figure 3 - Descriptive statistics of the volume of soil transported to termite mounds above surface level and total in five different locations. In parenthesis, number of termite mounds estimated in the area. 


\section{ACKNOWLEDGEMENTS}

This research was partially funded by PROBIC/UDESC, and authors thank Prof. Reginaldo Constatino for termite identification, Ana Claudia Rodrigues de Lima and Odair Alberton for helpful suggestions to the manuscript.

\section{REFERENCES}

BLACK, H.I.J.; OKWAKOL, M.J.N. Agricultural intensification, soil biodiversity and agroecosystem function in the tropics: the role of termites. Applied Soil Ecology, v.6, p.37-53, 1997.

BRAUMAN, A. Effect of gut transit and mound deposit on soil organic matter transformations in the soil feeding termite: A review. European Journal of Soil Biology, v.36, p.117-125, 2000.

BRUNE, A.; KÜHL, M. pH profiles of the extremely alkaline hindguts of soil-feeding termites (Isoptera: Termitidae) determined with microelectrodes. Journal of Insect Physiology, v.42, p.1121-1127, 1996.

BRUNE, A.; EMERSON, D.; BREZNAK, J.A. The termite gut microflora as an oxygen sink: microelectrode determination of oxygen and $\mathrm{pH}$ gradients in guts of lower and higher termites. Applied and Environmental Microbiology, v.61, p.26812687, 1995 .

DANGERFIELD, J.M.; MCCARTHY, T.S.; ELLERY, W.N. The mound-building termite Macrotermes michaelseni as an ecosystem engineer. Journal of Tropical Ecology, v.14, p.507520,1998

DONOVAN, S.E.; EGGLETON, P.; DUBBIN, W.E.; BATCHELDER, M.; DIBOG, L. The effect of a soil feeding termite, Cubitermes fungifaber (Isoptera: Termitidae) on soil properties: termites may be an important source of soil microhabitat heterogeneity in tropical forests. Pedobiologia, v. 45, p. $1-11,2001$.

EGGLETON, P.; TAYASU, I. Feeding groups, lifetypes and the global ecology of termites. Ecological Research, v.16, p.941960, 2001.

EMPRESA BRASILEIRA DE PESQUISA AGROPECUARIA. Serviço Nacional de Levantamento e Conservação de Solos. Manual de métodos de análise de solo. Rio de Janeiro: EMBRAPA, SNLCS, 1979.

FAO. Soil map of the world, revised legend. Rome: FAO; UNESCO, 1988. (World Soil Resources Report, 60).

HOLT, J.A. Microbial activity in the mounds of some Australian termites. Applied Soil Ecology, v.9, p.183-187, 1998.

JI, R., KAPPLER, A.; BRUNE, A. Transformation and mineralization of synthetic ${ }^{14} \mathrm{C}$-labeled humic model compounds by soil-feeding termites. Soil Biology \& Biochemistry, v.32, p.1281-1291, 2000 .

JONES, D.T.; SUSILO, F.X.; BIGNELL, D.E.; HARDIWINOTO, S.; GILLISON, A.N.; EGGLETON, P. Termite assemblage collapse along a land-use intensification gradient in lowland central Sumatra, Indonesia. Journal of Applied Ecology, v.40, p.380-391, 2003.

JOUQUET, P.; LEPAGE, M.; VELDE, B. Termite soil preferences and particle selections: strategies related to ecological requirements. Insectes Sociaux, v.49, p.1-7, 2002a.
JOUQUET, P.; MAMOU, L.; LEPAGE, M.; VELDE, B. Effect of termites on clay minerals in tropical soils: fungus-growing termites as weathering agents. European Journal of Soil Science, v.53, p.521-527, 2002b.

JUNGERIUS, P.D.; VAN DER ANCKER, J.A.M.; MÜCHER, H.J. The contribution of termites to the microgranular structure of soils on the Uasin Gishu Plateau, Kenya. Catena, v.34, p.349363, 1999.

LAL, R. Effects of macrofauna on soil properties in tropical ecosystems. Agriculture, Ecosystems and Environment, v.24, p.101-116, 1988.

LEE, K.E.; WOOD, T.G. Termites and soils. London: Academic Press, 1971. 251p.

LÉONARD, J.; RAJOT, J.L. Influence of termites on runoff and infiltration: quantification and analysis. Geoderma, v.104, p.17-40, 2001

LÓPEZ-HERNÁNDEZ, D. Nutrient dynamics ( $\mathrm{C}, \mathrm{N}$ and $\mathrm{P}$ ) in termite mounds of Nasutitermes ephratae from savannas of the Orinoco Llanos (Venezuela). Soil Biology \& Biochemistry, v.33, p.747-753, 2001.

MANDO, A.; STROOSNIJDER, L. The biological and physical role of mulch in the rehabilitation of crusted soil in Sahel. Soil Use and Management, v.15, p.123-127, 1999.

MIKLÓS, A.W. Biodinâmica da paisagem: organização e funcionamento biopedológico. Boletim do Instituto Biodinâmico de Desenvolvimento Rural, v.11, p.9-16, 1993.

MIKLÓS, A.W. Conceito ecológico do solo: o papel da biodiversidade na organização e dinâmica da cobertura pedológica. Curso de Agricultura Ecológica, 1, Campinas, 1995. Anais. Campinas: CTAE/SAA, 1995.

OHKUMA, M. Termite symbiotic systems: efficient bio-recycling of lignocellulose. Applied and Environmental Microbiology, v.61, p.1-9, 2003.

SANTA CATARINA (Estado). Gabinete de Planejamento e Coordenação Geral. Sub-chefia de Estatística, Geografia e Informática. Atlas de Santa Catarina. Rio de Janeiro: Aerofoto Cruzeiro, 1986. 176p.

SAS INSTITUTE INC. SAS user's guide: Statistics (Version 6.12) 4.ed. Cary: SAS Institute, 1999.

SCHULZE, D.G. An introduction to soil mineralogy. In: DIXON, J.B.; SCHULZE, D.G. (Ed). Soil mineralogy with environmental applications. Madison: SSSA, 2002. p.1-35.

SHAEFER, C.E. Brazilian latosols and their B horizon microstructure as long-term biotic constructs. Australian Journal of Soil Research, v.39, p.909-926, 2001.

SHEIKH, K.H.; KAYANI, S.A. Termite-affected soils in Pakistan. Soil Biology and Biochemistry, v.14, p.359-364, 1982.

TEDESCO, M.J.; VOLKWEISS, S.J.; BOHNEN, H. Análises de solo, plantas e outros materiais. Porto Alegre: UFRGS, Departamento de Solos da Faculdade de Agronomia,1985. (Boletim Técnico, 5).

WATSON, J.P. The composition of termite (Macrotermes spp.) mounds on soil derived from basic rock in three rainfall zones of Rhodesia. Geoderma, v.14, p.147-158, 1975.

WHITTIG, L.D.; ALLARDICE, W.R. X-ray diffraction techniques. In: KLUTE, A.; WEAVER, R.W.; SPARKS, D.L. (Ed). Methods of soil analysis. Part 1 . Physical and mineralogical methods. 2.ed. Madison: SSSA, 1986. p.331-362.

Received December 20, 2005

Accepted October 11, 2006 